\title{
Size matters in competition between corals and macroalgae
}

\author{
Renata Ferrari ${ }^{1, *}$, Manuel Gonzalez-Rivero ${ }^{2}$, Peter J. Mumby ${ }^{1,2}$ \\ ${ }^{1}$ Marine Spatial Ecology Lab, School of Biological Sciences, Goddard Building, University of Queensland, St. Lucia Campus, \\ Brisbane, Queensland 4072, Australia \\ ${ }^{2}$ Marine Spatial Ecology Lab, School of BioSciences, University of Exeter, Prince of Wales Road, Exeter EX4 4PS, UK
}

\begin{abstract}
Corals and macroalgae compete for space, but the influence of species and size on the competitive outcome is poorly understood. Using a manipulative experiment, we evaluated the effect of macroalgal competition on the growth rate of corals with an emphasis on the colony size, species identity and the intensity of competition. Coral-macroalgal competition was studied among 3 Caribbean coral species (Porites astreoides, Agaricia agaricites and Colpophyllia natans) and 2 macroalgal species (Lobophora variegata and Halimeda opuntia) for 1 yr. Two coral colony sizes were used and, for the smaller size class, 2 levels of intensity for macroalgal competition (25 and $100 \%$ contact with the coral perimeter). Coral size had the greatest effect on competitive outcome; 2 species of large corals under competition grew as much as controls and a third species did not lose tissue. All small colonies lost between 18 and $22 \%$ of their original area after a year of competing with macroalgae, and the competitive outcome was insensitive to algal species. Coral colony size is a critical factor for the competitive outcome with algae and the intensity of contact between competitors is not important in smaller corals. In general, our results support the theory that algal blooms can inhibit coral population dynamics by causing a bottleneck in the survivorship of smaller size classes.
\end{abstract}

KEY WORDS: Coral-macroalgal competition · Coral size · Porites astreoides · Agaricia agaricites · Colpophyllia natans $\cdot$ Lobophora variegata $\cdot$ Halimeda opuntia

\section{INTRODUCTION}

Macroalgae play an important role in the dynamics and function of coral reefs (McCook et al. 2001, Mumby \& Steneck 2008, Chadwick \& Morrow 2011, Fong \& Paul 2011) and have a detrimental effect on coral health, recruitment, survival, growth and fecundity (Bak \& Engel 1979, Tanner 1995, Hughes \& Tanner 2000, Nugues et al. 2004, Box \& Mumby 2007, Hughes et al. 2007, Foster et al. 2008, Arnold et al. 2010, Mumby \& Harborne 2010, Arnold \& Steneck 2011, Barott et al. 2011). Some studies have carried out a systematic analysis of competitive interactions across a range of coral and/or algal species (Lirman 2001, Nugues \& Bak 2006, Box \& Mumby 2007, Fos- ter et al. 2008, Rasher \& Hay 2010, Rasher et al. 2011). Where data are available, it appears that the outcomes of coral-algal competition vary among functional groups, and sometimes among species. For example, the flat creeping form of the brown alga Lobophora variegata (Lamouroux) can overgrow and kill corals (Jompa \& McCook 2002b, Box \& Mumby 2007), whereas Dictyota pulchella (Hörnig and Schnetter), with erect branching morphology, appears to have relatively minor effects on coral mortality (Hay 1981, River \& Edmunds 2001, Titlyanov et al. 2007, Hay 2009). However, a study found that 2 macroalgal species with erect branching morphology had different effects on coral recruits (Paul et al. 2011). Thus, the role of species identity 
remains uncertain in the outcome of coral-macroalgal competition.

In addition to species identity, size is an important trait in corals for congeneric competitive success, reproductive output and survival (Birkeland 1977, Zilberberg \& Edmunds 2001). A study that determined the competitive outcome among small colonies of Agaricia spp. found that larger colonies were dominant (Zilberberg \& Edmunds 2001). A positive relationship occurs between colony size and the number of larvae released by Porites astreoides (McGuire 1998), illustrating the importance of size for reproductive output. In a study investigating the traits that influence the relative abilities of corals to compete with algae, a significant negative relationship between mean colony size and percent of population area lost by 8 coral species was found (Hughes 1989). A recent study showed that Dictyota spp. can cause mortality of coral larvae and newly settled recruits, but has limited affect on larger corals (Paul et al. 2011). Nonetheless, most studies of coral-algal competition have investigated small coral colonies ( $<30 \mathrm{~cm}$ in diameter) and the importance of coral size in the outcome of the competition has not been previously examined explicitly.

Other factors that can influence the outcome of coral-algal competition include herbivory, water quality, disturbance, habitat, season and the specific coral and algal species (McCook et al. 2001, Jompa \& McCook 2002a, Hay \& Burkepile 2008, Ferrari et al. 2012). The detrimental effects of algal competition on corals are intensified on reefs with high algal abundance, which suggests that competitive intensity can also influence the outcome of coral-algal competition (Hughes 1994, Tanner 1995, Lirman 2001, Mumby 2006, Burkepile \& Hay 2010, Mumby \& Harborne 2010). Foster et al. (2008) studied the competitive effect of macroalgae on the fecundity of Montastraea annularis (Ellis and Solander) and found significantly smaller eggs in corals with $100 \%$ macroalgal contact than in corals with $50 \%$ macroalgal contact around their periphery. However, no studies of coral-algal competition have explicitly investigated the effects of competitive intensity on coral growth and survival (Mumby et al. 2006b).

In the present study, we systematically tested the effect of coral size, algal competitive intensity and the coral-algal species combination, on coral growth and survival. To do this, we used multiple coral and algal species (3 corals: Colpophyllia natans (Houttuyn), Porites astreoides (Lamarck) and Agaricia agaricites (Linnaeus), and 2 macroalgae: Lobophora variegata and Halimeda opuntia (Linnaeus)) to determine spe- cies-specific effects of different interactions. We also evaluated the effects of different coral colony sizes (small vs. large) and, for smaller corals, 2 levels of competitive intensity. We tested the following 3 hypotheses based on previous work (e.g. Bak \& Steward Van Es 1980, Nugues et al. 2004, Nugues \& Bak 2006, Box \& Mumby 2007, Mumby \& Harborne 2010):

$\mathrm{H}_{1}$ : A higher surface area provides the coral colony with a greater capacity to buffer the stress caused by competition with macroalgae. Hence, the severity of competition, in terms of reduction in coral growth rate and survival, will be inversely proportional to the colony's size.

$\mathrm{H}_{2}$ : The severity of competition, in terms of reduction in coral growth rate and survival, differs among coral-algal species competitive combinations.

$\mathrm{H}_{2 \mathrm{a}}$ : Susceptibility of corals to L. variegata: A. agaricites $>$ P. astreoides $>C$. natans).

$\mathrm{H}_{2 \mathrm{~b}}$ : Susceptibility of corals to H. opuntia: P. astreoides $>$ A. agaricites $>C$. natans).

$\mathrm{H}_{2 \mathrm{c}}$ : Severity of competition of algal species: H. opuntia > L. variegata.

$\mathrm{H}_{3}$ : The severity of competition, in terms of reduction in coral growth rate and survival, varies over competitive intensities in the following order $100 \%$ > $25 \%>0 \%$.

\section{MATERIALS AND METHODS}

\section{Study site and species selection}

This study was conducted on Glovers Reef Atoll $\left(87^{\circ} 48^{\prime} \mathrm{W}, 16^{\circ} 50^{\prime} \mathrm{N}\right)$, located $52 \mathrm{~km}$ offshore and $15 \mathrm{~km}$ east from the Mesoamerican Barrier Reef off Belize, Central America. The area was declared a nofishing reserve in 1993 (Carter \& Sedberry 1997) and has high levels of fish grazing for the Caribbean (Mumby 2006). The experiment was conducted on the forereef on the eastern side of the atoll at Long Caye wall, between January and December 2009. The forereef at Long Caye wall lies between 8 and $12 \mathrm{~m}$ of depth and is dominated by colonies of Montastraea annularis. The horizontal visibility is approximately $20 \mathrm{~m}$ along a transect line at a depth of $10 \mathrm{~m}$. The system has high wave energy and water flow because of its windward orientation (McClanahan \& Muthiga 1998, Renken \& Mumby 2009).

We studied 3 abundant coral species with contrasting life history strategies: a broadcast spawner, Colpophyllia natans, and 2 brooding species, Porites astreoides and Agaricia agaricites. C. natans was chosen because few coral-algal competition studies 
have investigated this species and it is potentially a strong competitor against macroalgae (Nugues et al. 2004). A. agaricites and $P$. astreoides were chosen because they employ a different reproductive strategy (brooders) and are the most common species of recruits found in Belize (Arnold \& Steneck 2011) and some of the most common in the Caribbean (Bak \& Engel 1979, Edmunds 2000). We selected 2 of the dominant macroalgal species on forereefs: Lobophora variegata and Halimeda opuntia (McClanahan et al. 1999, Mumby et al. 2005); hereafter referred to as Lobophora and Halimeda, respectively.

\section{Experimental design}

Coral colonies found on dead calcareous substrate were randomly selected. To avoid confounding effects of other potential benthic competitors, corals were not selected if they were directly adjacent to other sessile invertebrates, nor if they showed signs of damage or stress. Each colony was tagged and mapped using a compass bearing and distance from a fixed, easily referenced, point for repeated sampling.

\section{Coral colony size classes}

We investigated 2 colony size classes for each coral species. The small size class was approximately $10 \mathrm{~cm}$ in diameter $\left(100.04 \pm 5.95 \mathrm{~cm}^{2}[ \pm \mathrm{SE}]\right)$. The large size class for Colpophyllia natans and Porites astreoides was approximately $50 \mathrm{~cm}$ in diameter $\left(993.62 \pm 56.57 \mathrm{~cm}^{2}\right)$, whereas the large size class for Agaricia agaricites was approximately $30 \mathrm{~cm}$ in diameter $\left(494.54 \pm 54.92 \mathrm{~cm}^{2}\right)$. The large size class differed between $A$. agaricites and the other 2 species because of the size distribution of $A$. agaricites at our site (Table 1).

\section{Algal treatment}

Ten replicates of each coral size class and species were submitted to one of 3 algal treatments: control (1), Lobophora (2) and Halimeda (3). Preexisting macroalgae were cleared from around the periphery of each colony (10 cm belt) with wire brushes to standardize the experimental initial conditions. Care was taken not to harm the corals. Algae were then collected from a neighboring area and transplanted to the coral perimeter using zip ties attached to $15 \mathrm{~cm}$ stainless steel nails. This procedure varied according to the algal species. For Lobophora, rubble pieces heavily colonized by the alga were collected and attached next to the corals. Rubble pieces were checked to ensure that they were free of other potential competitors, such as sponges (González-Rivero et al. 2012). For Halimeda, large clumps were collected and placed in $1 \mathrm{~cm}$ nylon mesh hairnets. The holdfast of the algal clump was entangled to the centre of the hairnet and the thalli were left protruding outside the mesh. Only the fronds of either algal species were in direct contact with the perimeter of the coral colony (Fig. 1).

\section{Algal competitive intensity}

Three levels of competitive intensity were investigated for each algal species. (1) Controls or competitive intensity of $0 \%$, where all the algae around the perimeter of the coral colony were removed, and the cleared area was maintained. (2) Competitive intensity of $25 \%$, where $25 \%$ of the perimeter of the colony was maintained under algal contact (either Lobophora or Halimeda), while the rest was maintained clear of algae. (3) Competitive intensity of $100 \%$, where $100 \%$ of the perimeter of the colony was maintained under algal contact (either Lobophora or Halimeda). Levels 1 and 2 were applied to both small

Table 1. Summary of the experimental design per coral species and algal treatments. Percentages are the extent of the coral perimeter under macroalgal competition (competitive intensity level). As denoted by the minus sign (-), large colonies were only submitted to competitive intensity levels $0 \%$ and $25 \%$, while small colonies were submitted to the 3 levels (plus sign, + ). The minimal $n=10$ and we used a total of 240 coral colonies. The bottom row shows the total number of colonies per algal treatment and competitive intensity level

\begin{tabular}{|lccccccc|}
\hline \multirow{2}{*}{ Coral spp. } & Coral & \multicolumn{5}{c|}{ Algal treatment } \\
\cline { 3 - 7 } & size & Control & Lobophora & Halimeda \\
& & & \multicolumn{5}{c}{$\begin{array}{c}\text { variegata } \\
\text { opuntia }\end{array}$} \\
& & $0 \%$ & $25 \%$ & $100 \%$ & $25 \%$ & $100 \%$ \\
\hline Porites astreoides & Small & + & + & + & + & + \\
& Large & + & + & - & + & - \\
Agaricia agaricites & Small & + & + & + & + & + \\
Colpophyllia natans & Large & + & + & - & + & - \\
& Small & + & + & + & + & + \\
Total no. of colonies (240) & Large & + & + & - & + & - \\
& & 60 & 60 & 30 & 60 & 30 \\
\hline
\end{tabular}



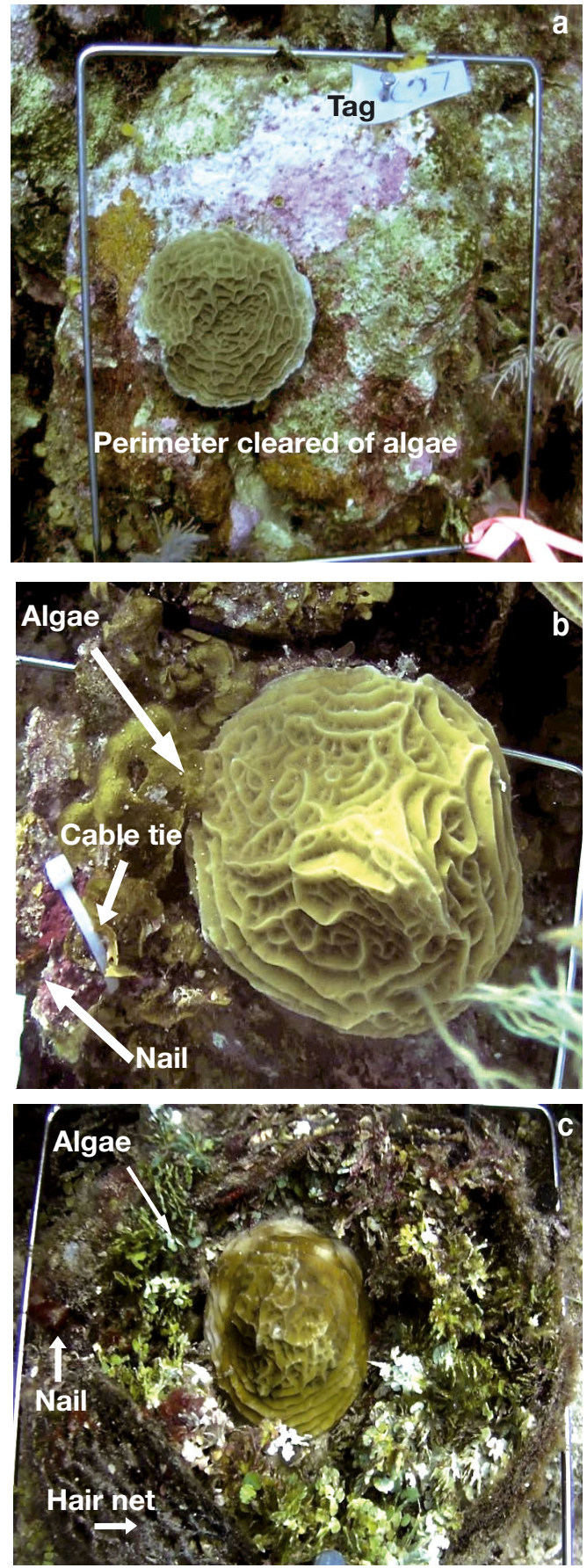

Fig. 1. The different algal treatments: (a) control, where all algae were cleared around the perimeter of the coral colony ( $0 \%$ competitive intensity level); (b) Lobophora variegata, where pieces of rubble with fronds of the algae were attached next to the coral colony using stainless steel nails and cable ties (25\% competitive intensity level); and (c) Halimeda opuntia, where clumps of the algae where collected and placed in hair nets (attached to the substrate using stainless steel nails) next to the coral colony (100\% competitive intensity level). The 3 coral colonies in these pictures are Agaricia agaricites and belong to the small size class (diameter $\sim 10 \mathrm{~cm}$ ) and large corals, while Level 3 was only applied to small corals. Note that the colonies without algal competition functioned simultaneously as the controls for the algal treatment and as the competitive intensity level of $0 \%$.

\section{Data collection and processing}

Corals were checked weekly for maintenance, algal clearance and replacement if necessary. During maintenance, all non-experimental algae were removed from the periphery of the corals according to each competitive intensity level; with the exception of crustose corallines whose removal can damage the structural integrity of the substratum. The experiment was set up in December 2008 and data were collected monthly from January to December 2009. Corals were filmed next to a quadrat $\left(625,2500\right.$ or $\left.5776 \mathrm{~cm}^{2}\right)$ for scale reference. Footage was processed with VidAna (Hedley 2006) to calculate the coral area and linear extension (largest diameter) of each colony.

\section{Statistical analysis}

The data were divided into 3 sets according to the 3 hypotheses (Table 2). Data set 1 was used to assess the effect of coral size on algal competition at both $0 \%$ contact (control) and $25 \%$ contact (note, the $100 \%$ contact treatment was excluded because this was only feasible in small corals). Data set 2 was used to quantify the effect of coral and algal species identity under one level of competitive intensity amongst the large corals (it excluded all the small corals). Data set 3 allowed comparisons of coral and algal species identity under 2 competitive intensity levels amongst the small corals (it excluded all the large corals). Linear models were fitted to test each of our 3 hypotheses. Coral growth was the response variable and it was calculated in 2 different ways: as area change (AC) of live tissue over time for Data set 1 (Eq. 1), and as the relative area change (RAC) of live tissue over time for Data sets 2 and 3 (Eq. 2). We used AC for Data set 1 , because the model comparing small and large corals includes initial coral size as a fixed effect. However, the models for Data sets 2 and 3 did not include size as a fixed effect, thus RAC was used as a response variable to take into account the possible effect of varying initial sizes. Both AC and RAC reflected a gain of colony area as a positive value and a loss in colony area as a negative value, and they were calculated as: 
Table 2. Summary of statistical analyses. Data were divided into 3 data sets. Coral growth was measured as area change (AC) in Data set 1 and as relative area change (RAC) in Data sets 2 and 3; both AC and RAC represented a continuous response variable. CSp = coral species, Cgrp = coral group (Porites astreoides (1) and Agaricia agaricites + Colpophyllia natans (2)), Ctyp = coral type (brooder or spawner), AlgT = algal treatment, AlgTt $=$ grouped algal treatment $($ control and algae), CSize $=$ coral size, and $\mathrm{Vs}=$ competitive intensity, $\mathrm{H}=$ hypothesis. Asterisks denote interaction, under the model column the type of model is shown in the first line, the original model is shown in the second line and the minimal adequate model is shown in the third line

\begin{tabular}{|c|c|c|c|c|}
\hline Data set & Question & Data used & Data excluded & Model \\
\hline 1 & $\begin{array}{l}\text { How does coral } \\
\text { growth vary between } \\
\text { coral sizes? } \mathrm{H}_{1}\end{array}$ & $\begin{array}{l}\text { All small and large corals } \\
\text { under } 0 \% \text { and } 25 \% \\
\text { competitive intensity }\end{array}$ & $\begin{array}{l}\text { Small corals under } 100 \% \\
\text { competitive intensity }\end{array}$ & $\begin{array}{l}\text { ANCOVA } \\
\text { AC } \sim \mathrm{CSize}^{*} \mathrm{CSp}^{*} \mathrm{AlgT} \\
\mathrm{AC} \sim \mathrm{CSize}^{*} \mathrm{Ctyp}+\mathrm{AlgTt}\end{array}$ \\
\hline 2 & $\begin{array}{l}\text { How does coral growth } \\
\text { vary with coral and algal } \\
\text { species identity in large } \\
\text { corals? } \mathrm{H}_{2 \mathrm{a}} \mathrm{H}_{2 \mathrm{~b}} \mathrm{H}_{2 \mathrm{c}}\end{array}$ & All large coral data & All small coral data & $\begin{array}{l}\text { ANOVA } \\
\text { RAC } \sim \mathrm{CSp}^{*} \mathrm{AlgT} \\
\text { RAC } \sim \operatorname{Cgrp}\end{array}$ \\
\hline 3 & $\begin{array}{l}\text { How does coral growth } \\
\text { vary with coral and algal } \\
\text { species identity and with } \\
\text { competitive intensity in } \\
\text { small corals? } \mathrm{H}_{2 \mathrm{a}} \mathrm{H}_{2 \mathrm{~b}} \mathrm{H}_{2 \mathrm{c}} \mathrm{H}_{3}\end{array}$ & All small coral data & All large coral data & $\begin{array}{l}\text { ANOVA } \\
\text { RAC } \sim \mathrm{CSp}^{*} \mathrm{AlgT}^{*} \mathrm{Vs} \\
\mathrm{RAC} \sim \mathrm{CSp}^{*} \mathrm{Vs}\end{array}$ \\
\hline
\end{tabular}

$$
\mathrm{AC}=A_{\mathrm{f}}-A_{\mathrm{i}}
$$

where $A_{\mathrm{f}}$ is the final colony area and $A_{\mathrm{i}}$ is the initial colony area.

$$
\mathrm{RAC}=\left(\mathrm{AC} / A_{\mathrm{i}}\right) \times 100
$$

where $\mathrm{AC}$ is the total change in surface area of the colony across the study duration and $A_{\mathrm{i}}$ is the initial colony area.

We used an analysis of covariance (ANCOVA) to compare the outcome of the coral-macroalgal competition between small and large corals $\left(\mathrm{H}_{1}\right)$. AC was our response variable and initial coral size was included as a covariate to account for the difference in initial size among different colonies, while coral species (3 levels) and algal treatment (3 levels) were included as categorical explanatory variables. An analysis of variance (ANOVA) was run to assess the effect of coral species identity $\left(\mathrm{H}_{2 \mathrm{a}}\right.$ and $\left.\mathrm{H}_{2 \mathrm{~b}}\right)$ and algal treatment $\left(\mathrm{H}_{2 \mathrm{c}}\right)$ (categorical explanatory variables) on the growth of large corals. A second ANOVA was run to assess the effect of coral species identity $\left(\mathrm{H}_{2 \mathrm{a}}\right.$ and $\left.\mathrm{H}_{2 b}\right)$, algal treatment $\left(\mathrm{H}_{2 \mathrm{c}}\right)$ and competitive intensity $\left(\mathrm{H}_{3}\right)$ (categorical explanatory variables) on the growth of small corals. RAC was the response variable for both ANOVAs.

Interactions among the explanatory variables were tested in all models. Non-significant interactions and factors were eliminated following the parsimony principle to obtain the minimal adequate model. Linear model (not shown) and Tukey HSD post-hoc tests determined whether within-level effects were significant for the categorical variables with 3 or more levels. If 2 levels did not differ significantly, they were combined for simplification and the new model compared against the more complex model using ANOVA. For example, it was possible to simplify the ANCOVA by merging 2 coral species (the brooders) into one category. Hence, the new categorical variable was coral type, where the 2 levels were brooders (Porites astreoides and Agaricia agaricites) and spawner (Colpophyllia natans). Residuals were plotted to check that the models conformed to the assumptions of normality and homogeneity of variance. Additionally, we tested the distribution of residuals using a Fligner-Killeen test. The residuals displayed no departure from homogeneity of variance, but slightly departed from normality. Nonetheless, linear regression is reasonably robust against the violation of the normality assumption (Greenberg 2004, Faraway 2006, Zuur et al. 2010). Thus, we decided to preserve these as the final models because the residuals were distributed homogenously (Fligner-Killeen test $\mathrm{p}$-value $=0.7777$ for dataset $1, p$-value $=0.6319$ for large corals and $\mathrm{p}$-value $=0.9588$ for small corals). Using data from a single experiment to test multiple hypotheses increases the chances of Type I error, when the null hypothesis is incorrectly rejected. We used adjusted $\mathrm{p}$-values $(\mathrm{p}<0.01)$ to avoid significant results as a consequence of multiple testing of the same data and we provide the exact p-values. Finally, we used the best fitting models to highlight graphically the relative effect of different drivers on coral growth. We used the final model in Data set 1 (Table 2) to predict the area change for corals within the studied size range (20 and $3000 \mathrm{~cm}^{2}$ ). 


\section{RESULTS}

\section{Effect of coral colony size on coral growth $\left(\mathrm{H}_{1}\right)$}

When competing with macroalgae, only large corals were able to grow, while small corals suffered total or partial mortality (Fig. 2a). Under control conditions, all corals exhibited growth: on average large corals grew $125.84 \pm 26.98 \mathrm{~cm}^{2}$ ( 2.5 to $4.5 \%$ of their original area) and small corals grew $12.75 \pm$ $13.29 \mathrm{~cm}^{2}$ ( 0 to $4 \%$ of their original area). The interaction between coral size and coral type (brooders and spawner) was significant, the effect of size being more important for spawner than for brooding corals (Table 3). The correlation between growth and colony size was stronger for the large spawner than

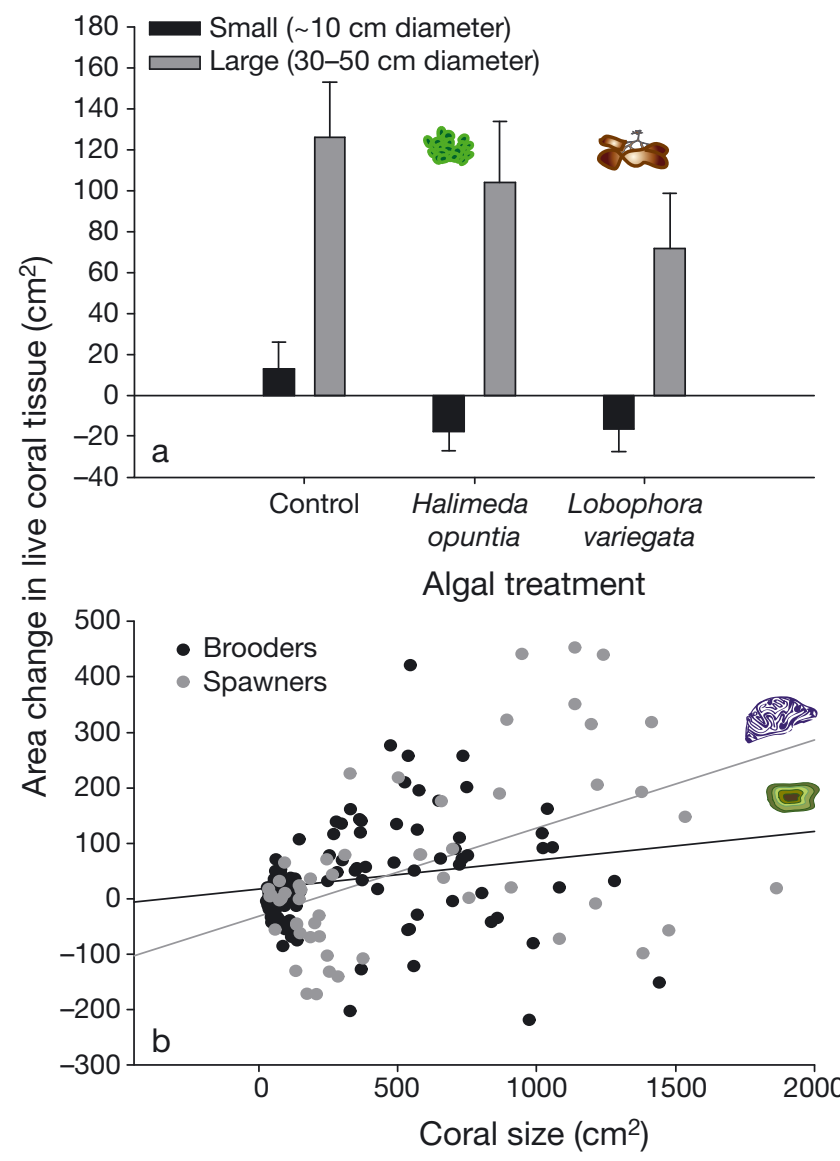

Fig. 2. Effect of colony size on coral growth $\left(\mathrm{H}_{1}\right)$. (a) Under control conditions all corals exhibited growth, but when competing with macroalgae only large corals were able to grow, while small corals suffered total or partial mortality. Error bars denote standard errors (SE). (b) Coral type and size interacted so that size was more important for the growth of spawners (Colpophyllia natans) than for the growth of brooders (Porites astreoides and Agaricia agaricites), which is expressed as a steeper slope
Table 3. Effect of colony size on coral growth $\left(\mathrm{H}_{1}\right)$. ANCOVA showing the direct and interactive effects of coral type (brooder and spawner), grouped algal treatment (control and algae) and coral size on coral growth

\begin{tabular}{|lrrcl|}
\hline Factor & df & MS & $F$ & \multicolumn{1}{c|}{$p$} \\
\hline Treatment & 1 & 45466 & 3.9574 & 0.04 \\
Coral type & 1 & 23287 & 2.0269 & 0.1565 \\
Size & 1 & 294365 & 25.622 & 0.000001 \\
Size $\times$ Coral type & 1 & 76100 & 6.6238 & 0.01 \\
Error & 161 & 11489 & & \\
\hline
\end{tabular}

for the brooders (Fig. 2b). Thus, we accept $\mathrm{H}_{1}$, because the severity of competition was inversely proportional to the colony's size for all corals. The posthoc test revealed that the area change was not significantly different between Lobophora and Halimeda ( $\mathrm{p}=0.751)$, nor between Porites astreoides and Agaricia agaricites $(\mathrm{p}=0.767)$; hence, we simplified coral species to coral type (brooders and spawner) and algal treatment to a categorical variable with 2 levels (controls and algae). Fig. 3 shows the linear relationship between predicted area change and colony size for brooders and spawner, in control and algal treatments. The initial model tested the 3-way interaction between coral species, algal species and size, but the interaction was not significant $(p=0.58$, $F$-value $=0.718, \mathrm{df}=4)$.

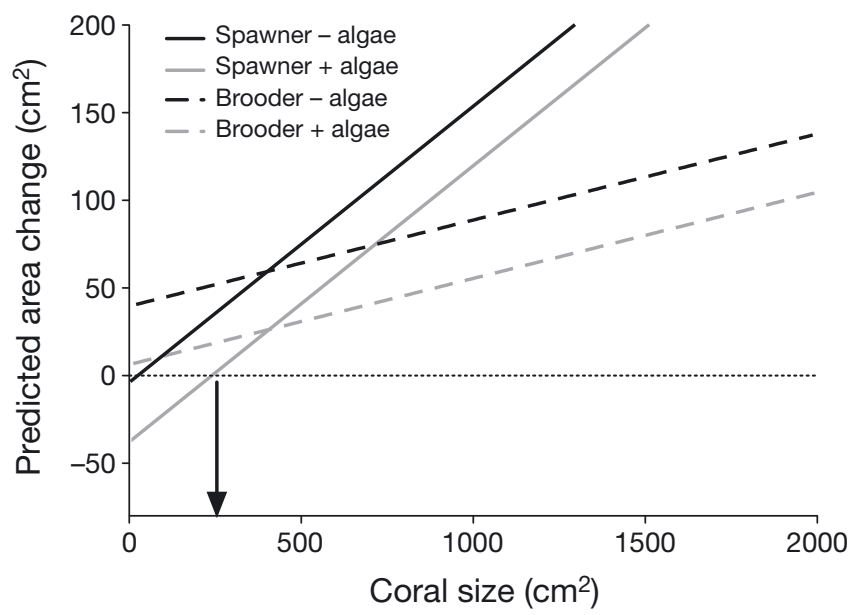

Fig. 3. Linear regression of the predicted area change of live coral tissue in 2 brooders (Porites astreoides and Agaricia agaricites) and a broadcast spawning coral (Colpophyllia natans), competing (gray) and not competing (black) with macroalgae (Lobophora variegata or Halimeda opuntia). Our model predicts that coral size is more important for C. natans than for the brooding corals, and C. natans colonies larger than $\sim 250 \mathrm{~cm}^{2}$ are able to grow even when competing with macroalgae (threshold denoted by the arrow) 


\section{Effect of species identities on coral growth $\left(\mathrm{H}_{2}\right)$}

All 3 large coral species responded similarly to competition with Halimeda (Fig. 4), exhibiting net growth of 12 to $22 \%$; neither was there a difference in susceptibility to Lobophora between Agaricia agaricites and Colpophyllia natans, with both species exhibiting net growth of 17 to $26 \%$ (Fig. 4). Controls grew between 14 to $25 \%$ and there was not a significant effect of algal treatment on the relative area change of large corals (Table 4). For large coral colonies, the severity of algal competition on coral growth only differed significantly in 1 out of 6 possible combinations of coral-algal competition (Porites astreoides with Lobophora). Large colonies of P. astreoides failed to grow after a year of competition with Lobophora (Fig. 4). We therefore simplified the analysis of the responses of large corals to pool the indistinguishable responses of $A$. agaricites and $C$. natans (group 1) and retain $P$. astreoides as the second group. Coral group had a significant ( $\mathrm{p} \leq$ 0.01) effect on the growth of large colonies, but algal treatment had no significant effect (Table 4). The initial model tested the 2-way interaction between coral species and algal treatment; this interaction was not significant $(\mathrm{p}=0.617, F$-value $=0.667$, $\mathrm{df}=4)$. Overall, we reject $\mathrm{H}_{2}$ for large corals, because the severity

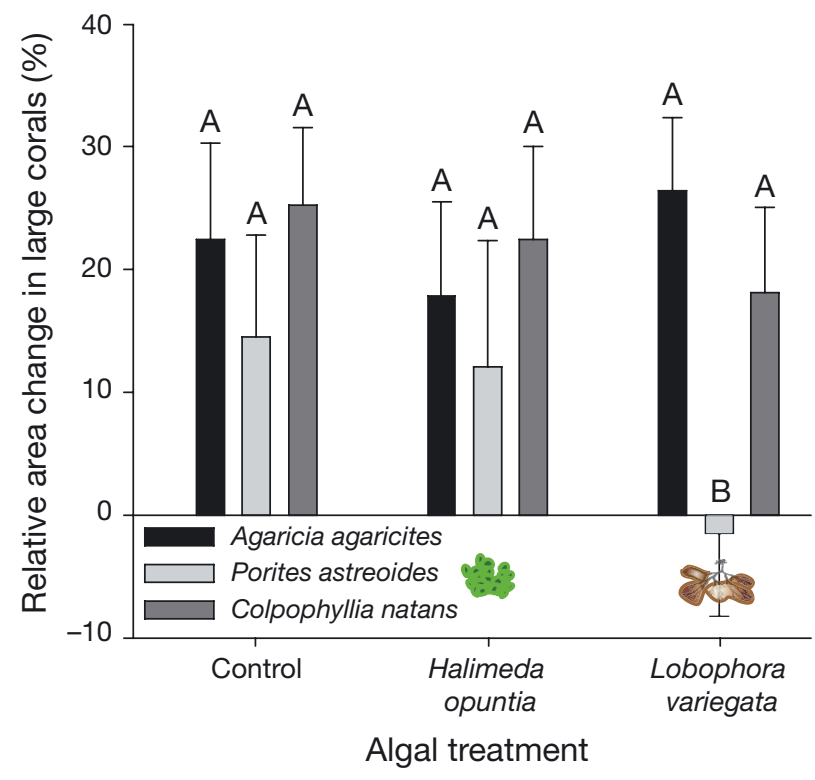

Fig. 4. Effect of coral-algal species combinations on coral growth for large corals $\left(\mathrm{H}_{2}\right)$ : Coral growth did not differ among coral species for the control or the Halimeda opuntia treatments; however, large Porites astreoides was very susceptible to competition with Lobophora variegata compared to other coral species. Error bars represent SE, and letters denote significant differences in relative area change among groups $(\mathrm{p}<0.05)$
Table 4. Effect of coral-algal species combinations on growth of large corals $\left(\mathrm{H}_{2}\right)$. ANOVA showing the direct and interactive effects of coral group (where Colpophyllia natans and Agaricia agaricites were grouped together and Porites astreoides formed a second group of a single species) and algal treatment (control, Lobophora variegata and Halimeda opuntia) on coral growth. While coral growth significantly differed between coral groups, their susceptibility to macroalgal treatment did not differ significantly

\begin{tabular}{|lrrcc|}
\hline Factor & df & MS & $F$ & $\mathrm{p}$ \\
\hline Treatment & 2 & 228.3 & 0.4626 & 0.631 \\
Coral group & 1 & 3570.2 & 7.2354 & 0.008 \\
Treatment $\times$ Coral group & 2 & 477.1 & 0.9670 & 0.385 \\
Errors & 73 & 493.4 & & \\
\hline
\end{tabular}

of macroalgal competition on coral growth was only different for 1 out of 6 competitive combinations among the large corals.

In the absence of algal competition, the growth of small coral colonies differed among species, with Agaricia agaricites growing the fastest ( 20\%), followed by Porites astreoides ( 10\%) and Colpophyllia natans $(\sim-5 \%)$. Small coral colonies always exhibited shrinkage when in contact with macroalgae (Fig. 5), but the magnitude of effect did not vary with species identity (Table 5). Thus, we reject $\mathrm{H}_{2 \mathrm{a}}, \mathrm{H}_{2 \mathrm{~b}}$ and $\mathrm{H}_{2 \mathrm{c}}$ for the small corals.

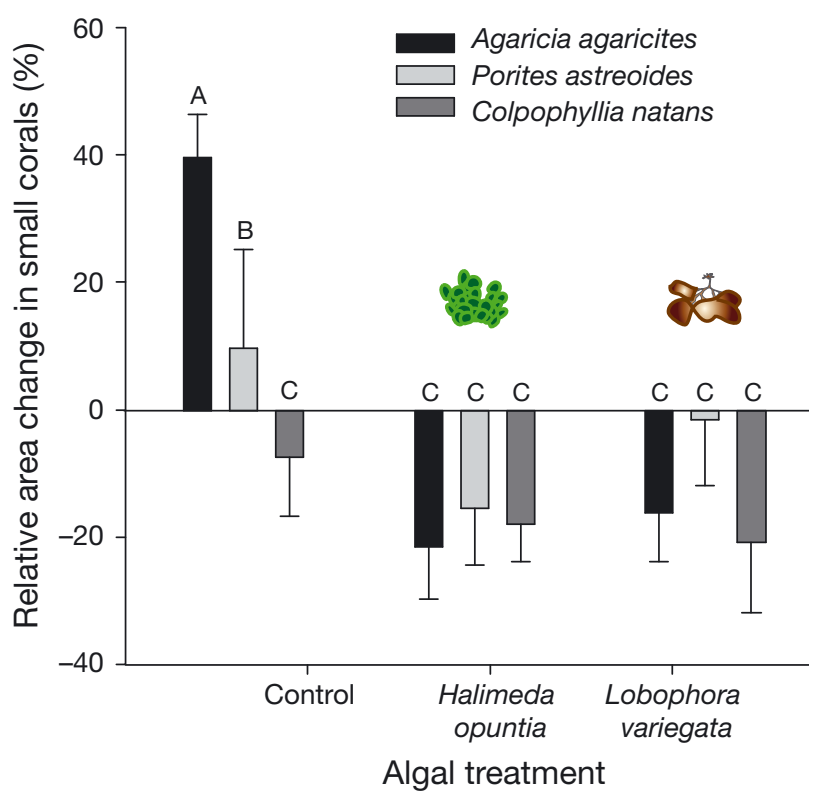

Fig. 5. Effect of coral-algal species combinations on coral growth for small corals $\left(\mathrm{H}_{2}\right)$. Coral growth was impaired by competition of both macroalgal species, and it did not differ among coral species. Coral growth only differed significantly among coral species in the control treatment. Error bars represent SE and letters denote significant differences in relative area change among groups $(p<0.05)$ 


\section{Effect of competitive intensity on coral growth $\left(\mathrm{H}_{3}\right)$}

In general, the growth of small corals was hampered by the presence of algae, but it was not significantly related to the intensity of competition with algae around the colony's periphery (Fig. 6, Table 5). Small corals under $100 \%$ macroalgal competition lost more tissue than those under $25 \%$ (Fig. 6), but the only significant differences were found between $0 \%$ and $25 \%$ or $100 \%$, not between $25 \%$ and $100 \%$ (Table $6,0 \%<25 \%=100 \%$ ). The patterns varied with coral species identity; both levels of competition significantly reduced the growth of Agaricia agaricites (linear model parameters with $0 \%$ as the intercept $\mathrm{p}_{100 \%}<0.0001, t=-4.035, \mathrm{p}_{25 \%}<0.001, t=$ $-3.494)$, and this coral species grew in the control $(0 \%)$ treatment. Porites astreoides only lost tissue in the $100 \%$ intensity treatment, and did not grow or lose tissue in the $0 \%$ or $25 \%$ treatments $\left(\mathrm{p}_{100 \%}=\right.$ $\left.0.072, t=-1.811, \mathrm{p}_{25 \%}=0.52, t=-0.645\right)$. The effect of macroalgal competition on the growth of Colpophyllia natans was not significantly different among any level of competitive intensity, yet this species underwent colony shrinkage under both levels of competitive intensity ( $25 \%$ and $100 \%$ ) and did not lose tissue or grow in the control treatment (Fig. 6). The patterns found were consistent for both algal species involved in the competitive interactions (i.e. algal species had no significant additive effect on the outcome). The post-hoc test confirmed that the difference between $25 \%$ and $100 \%$ was not statistically different, and that the difference between $0 \%$ and both $25 \%$ and $100 \%$ was statistically significant

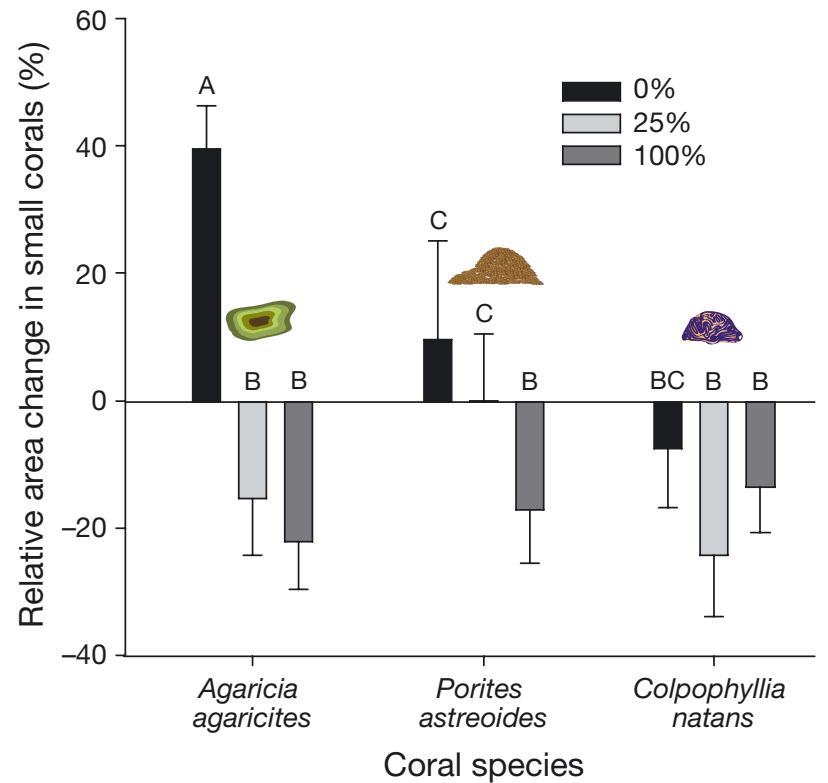

Fig. 6. Effect of competitive intensity on small coral growth $\left(\mathrm{H}_{3}\right)$ : the degree to which coral growth was impaired by macroalgal competition was not significantly different between $25 \%$ and $100 \%$ competitive intensity for any of the 3 coral species we studied. The difference was significant between $0 \%$ and both $25 \%$ and $100 \%$ for Agaricia agaricites and Porites astreoides. Colpophyllia natans did not grow in $0 \%$ competitive intensity and lost tissue in both $25 \%$ and $100 \%$ competitive intensities. Error bars represent SE and letters denote significant differences in relative area change among groups $(\mathrm{p}<0.05)$

(Table 6). We conclude, therefore, that the severity of competition is not significant for the growth of small corals, but that algal presence is highly significant (Tables 5 \& 6).
Table 5. Effect of coral-algal species combinations and competitive intensity levels on small coral growth $\left(\mathrm{H}_{2}\right.$ and $\left.\mathrm{H}_{3}\right)$. ANOVA showing the direct and interactive effects of competitive intensity $(0 \%, 25 \%$ and $100 \%)$, algal treatment (control, Lobophora variegata and Halimeda opuntia) and coral species (Agaricia agaricites, Colpophyllia natans and Porites astreoides) on the growth of small colonies. Coral growth varied with species identity in the control colonies, but it did not in either of the competitive intensity treatments. While there was not a significant difference between $25 \%$ and $100 \%$ levels of competitive intensity, the difference between these levels and $0 \%$ level was highly significant

\begin{tabular}{|lrrrr|}
\hline & df & MS & $F$ & $p$ \\
\hline Competitive intensity & 2 & 21558 & 7.2318 & 0.001 \\
Treatment & 1 & 814 & 0.5462 & 0.461 \\
Coral species & 2 & 3089 & 1.0361 & 0.358 \\
Competitive intensity $\times$ Treatment & 1 & 682 & 0.4577 & 0.499 \\
Competitive intensity $\times$ Coral species & 4 & 12198 & 2.0460 & 0.091 \\
Treatment $\times$ Coral species & 2 & 1097 & 0.3679 & 0.693 \\
Competition intensity $\times$ Treatment $\times$ Coral sp. & 2 & 1091 & 0.3659 & 0.694 \\
Error & 126 & 1490.5 & & \\
\hline
\end{tabular}

\section{DISCUSSION}

The present study reveals that the capacity of a coral to withstand macroalgal competition will depend mainly upon its size. In our study, large corals competing with macroalgae were able to grow, while small corals suffered partial or total mortality. Corals in both size classes grew when macroalgae were not present, except for small Colpophyllia natans. Two species of large corals grew regardless of the algal species they were competing with, while large colonies of Porites astreoides grew when competing with Halimeda, but did not grow when competing with Lobophora. 
Table 6. Tukey HSD post-hoc test within levels of competitive intensity. While $0 \%$ differed significantly from both $25 \%$ and $100 \%$, there was not a statistical difference between $25 \%$ and $100 \%$ across coral species and algal treatments

\begin{tabular}{|lcl|}
\hline Competitive intensity level & Difference & \multicolumn{1}{c|}{$p$} \\
\hline $0 \%$ vs. $25 \%$ & -29.986 & 0.004 \\
$0 \%$ vs $100 \%$ & -34.044 & 0.0009 \\
$25 \%$ vs. $100 \%$ & -4.058 & 0.838 \\
\hline
\end{tabular}

While size is not always critical for survival even within species of the same group and growth (Turon \& Becerro 1992), previous studies show that size can be a key trait for the growth, reproduction and survival of benthic marine organisms (Buss 1980, Sebens 1982, Soong 1993, Meesters et al. 1996, Zilberberg \& Edmunds 2001, Mumby \& Harborne 2010). Our results extend this conclusion to the outcome of coral-macroalgal competition. Our results suggest that past a certain size threshold corals are capable of growing normally in the presence of 2 common species of macroalgae. Thus, a reef with high abundance of corals whose diameter exceeds $30 \mathrm{~cm}$ in Agaricia agaricites or $50 \mathrm{~cm}$ in Porites astreoides and Colpophyllia natans is likely to have a greater capacity to survive macroalgal blooms (Fig. 3).

In large corals, species identity was only important in 1 out of 6 combinations of competitors (Porites astreoides vs. Lobophora variegata). P. astreoides has been reported to be highly susceptible to algal overgrowth compared to other Caribbean coral species (Sammarco 1980, 1982, Nugues et al. 2004, Kuffner et al. 2006). Our data are consistent with this interpretation once corals reach a larger colony size (exceeding $30 \mathrm{~cm}$ in diameter). Agaricia agaricites has previously been found to be more susceptible to macroalgal competition than $P$. astreoides (Nugues \& Bak 2006, Mumby \& Harborne 2010). However, we conclude that large $A$. agaricites was a stronger competitor with Lobophora than $P$. astreoides. The 2 previous studies only looked at small colonies $\left(250 \mathrm{~cm}^{2}\right.$ colonies by Nugues \& Bak 2006, and typically 1 to $150 \mathrm{~cm}^{2}$ sized colonies by Mumby \& Harborne 2010), and therefore the apparent discrepancy might be explained by the difference in coral sizes among studies.

Previous studies found that negative effects of macroalgae on the growth of small corals vary among coral species (Lirman 2001, Jompa \& McCook 2002b, Nugues \& Bak 2006, Haas et al. 2010). Lirman (2001) compared the effect of macroalgal competition ( $50 \%$ macroalgal cover) on 2 small (5 to $15 \mathrm{~cm}$ in diameter) corals (Porites astreoides and Siderastrea siderea), and found that $P$. astreoides was susceptible to macroalgal competition, while $S$. siderea was not. Mumby \& Harborne (2010) reported on small colonies of 5 species (Agaricia agaricites, P. astreoides, S. siderea, Montastraea annularis and $M$. faveolata), and found that $A$. agaricites, $P$. astreoides and $M$. annularis were susceptible to macroalgal competition, while $S$. siderea and M. faveolata were less so. Our data are consistent with both studies because we found that small colonies of both $A$. agaricites and $P$. astreoides lose tissue significantly when competing with macroalgae. Our results are also broadly consistent with some of those from Nugues \& Bak (2006), who looked at the effect of competition between Lobophora and small colonies of 6 coral species (A. agaricites, A. lamarcki, P. astreoides, Mycetophyllia alicea, Meandrina meandrites and Montastraea franksi). Nugues \& Bak (2006) found that only $A$. agaricites significantly lost tissue and was overgrown by Lobophora, and no significant tissue loss was found among the remaining coral species.

While previous reviews agree that the outcome of the competitive interaction varies among species (McCook et al. 2001, Birrell et al. 2008, Chadwick \& Morrow 2011), our results failed to detect an effect of algal species on the outcome of the competition. Our control for algal treatment $(0 \%)$ assessed coral growth in the absence of macroalgae, but did not allow discrimination of the effects of different algal properties on coral growth. Algae can affect corals through different mechanisms; for example, it can change the amount of dissolved oxygen in the neighboring boundary layer (Smith et al. 2006, Barott et al. 2011), harbour disease (Nugues et al. 2004) and produce secondary metabolites for allelopathy (Paul et al. 2011, Rasher et al. 2011). The present study was not designed to test the various mechanistic effects of different macroalgal species, but to explore the overall effect of different macroalgal species on different coral species and sizes. One mechanism that was not addressed by the study design is the effect of space occupation near corals, which might reduce water flow and potentially the supply of food. To test for this, we would have needed to create a further treatment with an algal mimic, such as plastic (see Box \& Mumby 2007 or Rasher et al. 2011). A previous study that included a mimic of Dictyota pulchella found that it exerted a similar negative influence on the growth of juvenile Agaricia agaricites as the alga (Box \& Mumby 2007). Thus, a potential explanation for the similarity in effects among algal species is that the presence of an alga may cause sufficient stress on the coral regardless of any differences among algal species in allelochemical effects or bacterial processes. 
Although coral species identity was generally unimportant in our analysis, we did find variability among coral species in the susceptibility of small corals to different levels of competitive intensity. All 3 coral species shrunk when competing with macroalgae on $100 \%$ of their perimeter. Only 2 coral species (Agaricia agaricites and Colpophyllia natans) lost tissue when competing with macroalgae on $25 \%$ of their perimeter; while Porites astreoides remained in near-stasis when competing with $25 \%$ macroalgae. If corals do indeed reach a size-escape from competition with macroalgae, our results suggest that threshold responses of corals may differ in subtle ways according to the intensity of the competitive interaction. Chronic effects were found for the effects of Dictyota spp. and Lobophora on the fecundity of the large massive corals, Montastraea annularis (Foster et al. 2008), such that mean egg size was significantly smaller in corals with a higher percent of their perimeter $(100 \%)$ exposed to algal contact, than in corals exposed to less algal contact (50\%); and these had significantly smaller eggs than colonies that were not in direct contact with algae $(0 \%)$.

Colpophyllia natans was the only species of small coral that did not grow in control treatments, and it lost area in the algal treatments. It is difficult to explain this result, but it implies that some other process was preventing growth or inducing partial mortality in this species during the experiment (e.g. black band disease, which does not affect Porites astreoides or Agaricia agaricites and can be lethal for C. natans; Whelan et al. 2007). Thus, we have to be cautious in interpreting the lack of a significant effect of competition intensity or algal competition on small colonies of this species. Black band disease was observed in some colonies of $C$. natans at our site. However, none of the colonies under study showed any symptoms of disease throughout 2009 (R. Ferrari pers. obs.).

It is important to recognise that these experiments were undertaken in offshore, windward environments that tend to have higher primary productivity than leeward systems (Renken et al. 2010) and that experimental outcomes might differ in a habitat of lower productivity. Macroalgae on leeward systems tend to grow more slowly and reach smaller patch sizes (Renken et al. 2010). This could affect the outcome of coral-algal competitive interactions by reducing the duration and frequency of interactions, and thereby favouring coral.

Disentangling the mechanisms by which species and colony size influence the outcome of competition with algae is difficult. This is partly because the morphology of a coral often varies among species and during ontogeny. Morphology is likely to influence the outcome of competition, because it will influence the extent of the coral perimeter under direct macroalgal contact (Hughes 1989, Lang \& Chornesky 1990, Tanner 1995, Lirman 2001). Unfortunately, our use of only 3 coral species, all of which exhibit an encrusting morphology when small and either an encrusting or massive morphology when larger, prevents us from adding any further insight into the effects of morphology per se. Conversely, encrusting and massive morphologies have been identified as highly susceptible to macroalgal competition (Hughes 1989, Haas et al. 2010). Thus, our study evaluated how variables such as species identity, colony size and intensity of competition may confer competitive success to corals of the most susceptible morphologies.

Given the limited number of species studied, we must be cautious in the interpretation of our results with regards to coral type (spawners vs. brooders). Nonetheless, our results generate a hypothesis that could be tested in the future. It is well established that spawners are heavily under-represented in the assemblage of juvenile corals on Caribbean reefs (Bak \& Engel 1979, Rogers et al. 1984, Mumby 1999, Edmunds 2000, Arnold et al. 2010), yet the paucity of juveniles is difficult to explain, particularly since spawners often dominate the adult assemblage. In our study, the spawner experienced a greater reduction in growth than the brooders when in contact with algae. While this may simply reflect interspecific variability, it would be worth testing whether this applied generally among spawners and, if so, whether it may help explain the continued paucity of juveniles.

Macroalgal blooms may arise from various natural and anthropogenic causes, and can have detrimental effects on the health of a reef (Carpenter 1986, Mumby et al. 2006a, Hay \& Burkepile 2008). We have identified a coral species, Porites astreoides, that is highly susceptible to competition with Lobophora. We also confirmed that the severity of macroalgal competition on coral growth increases with macroalgal abundance. Our results suggest that the response of corals to an algal bloom will be strongly influenced by the colony size distribution, and that a size threshold likely exists, beyond which coral colonies are able to survive and outcompete macroalgae (Birkeland 1977, Vermeij \& Sandin 2008). In general, our results provide further empirical support to the theory that algal blooms can inhibit coral population dynamics by causing a bottleneck in the survivorship of smaller size classes (Mumby et al. 2007, Mumby \& Steneck 2008, Arnold et al. 2010). Size distributions will continue to be a key factor for interpreting the potential 
vulnerability or resilience of a reef (Done et al. 1996, Meesters et al. 1997, Done 1999). Fortunately, variables such as coral size frequency, macroalgal abundance and species distribution are commonly obtained through monitoring protocols, such as the Atlantic and Gulf Rapid Reef Assessment (Kramer et al. 2003).

Acknowledgements. This study was funded by a Khaled bin Sultan Living Oceans Foundation and a Wildlife Conservation Society Research Leadership Program Fellowships (to R.F.), and supported by an ARC Laureate Fellowship (to P.J.M.). R.F. was funded by a Comisión Nacional de Ciencia y Tecnología (CoNaCyT) of México, an ORSAS University of Exeter and a University of Queensland scholarships. M.G.-R. was funded by the Fondo Nacional de Ciencia, Tecnología e Innovación (FONACIT) of Venezuela. We thank volunteers for field and lab assistance and the staff at the Glovers Reef Marine Station for invaluable field support. We also thank the Fisheries Department of Belize for issuing the research permit. Comments by 2 anonymous referees greatly improved the manuscript.

\section{LITERATURE CITED}

Arnold SN, Steneck RS (2011) Settling into an increasingly hostile world: the rapidly closing 'recruitment window' for corals. PLoS ONE 6:e28681

> Arnold SN, Steneck RS, Mumby PJ (2010) Running the gauntlet: inhibitory effects of algal turfs on the processes of coral recruitment. Mar Ecol Prog Ser 414:91-105

> Bak RPM, Engel MS (1979) Distribution, abundance and survival of juvenile hermatypic corals (Scleractinia) and the importance of life history strategies in the parent coral community. Mar Biol 54:341-352

Bak RPM, Steward Van Es Y (1980) Regeneration of superficial damage in the scleractinian corals Agaricia agaricites, F. purpurea and Porites astreoides. Bull Mar Sci 30:883-887

Barott KL, Rodriguez-Brito B, Janouskovec J, Marhaver KL, Smith JE, Keeling P, Rohwer FL (2011) Microbial diversity associated with four functional groups of benthic reef algae and the reef-building coral Montastraea annularis. Environ Microbiol 13:1192-1204

Birkeland C (1977) The importance of rate of biomass accumulation in early successional stages of benthic communities to the survival of coral recruits. Proc 3rd Int Coral Reef Symp, Miami, FL, p 15-21

Birrell CL, McCook LJ, Willis BL, Diaz-Pulido GA (2008) Effects of benthic algae on the replenishment of corals and the implications for the resilience of coral reefs. Oceanogr Mar Biol Annu Rev 46:25-63

Box SJ, Mumby PJ (2007) Effect of macroalgal competition on growth and survival of juvenile Caribbean corals. Mar Ecol Prog Ser 342:139-149

Burkepile DE, Hay ME (2008) Herbivore species richness and feeding complementarity affect community structure and function on a coral reef. Proc Natl Acad Sci USA 105: 16201-16206

Burkepile DE, Hay ME (2010) Impact of herbivore identity on algal succession and coral growth on a Caribbean reef. PLoS ONE 5:e8963

Buss LW (1980) Competitive intransitivity and sizefrequency distributions of interacting populations. Proc Natl Acad Sci USA 77:5355-5359
Carpenter RC (1986) Partitioning herbivory and its effects on coral reef algal communities. Ecol Monogr 56:345-363

Carter J, Sedberry GR (1997) The design, function and use of marine fishery reserves as tools for the management and conservation of the Belize Barrier Reef. Proc Int Coral Reef Symp 2:1911-1916

Chadwick NE, Morrow KM (2011) Competition among sessile organisms on coral reefs coral reefs. In: Dubinsky Z, Stambler N (eds) An ecosystem in transition. Springer, Dordrecht, p 347-371

Done TJ (1999) Coral community adaptability to environmental change at the scales of regions, reefs and reef zones. Am Zool 39:66-79

Done TJ, Ogden JC, Wiebe WJ, Rosen BR (1996) Biodiversity and ecosystem function of coral reefs. In: Mooney HA, Cushman JH, Medina E, Sala OE, Schulze ED (eds) Functional roles of biodiversity: a global perspective. John Wiley \& Sons, New York, NY p 393-429

Edmunds PJ (2000) Patterns in the distribution of juvenile corals and coral reef community structure in St. John, US Virgin Islands. Mar Ecol Prog Ser 202:113-124

Faraway JJ (2006) Extending the linear model with R: generalized linear, mixed effects and nonparametric regression models. Taylor \& Francis Group, Boca Raton, FL

Ferrari R, Gonzalez-Rivero M, Ortiz JC, Mumby PJ (2012) Interaction of herbivory and seasonality on the dynamics of Caribbean macroalgae. Coral Reefs 31:683-692

Fong P, Paul VJ (2011) Coral reef algae coral reefs. In: Dubinsky Z, Stambler N (eds) An ecosystem in transition. Springer, Dordrecht, p 241-272

> Foster NL, Box SJ, Mumby PJ (2008) Competitive effects of macroalgae on the fecundity of the reef-building coral Montastraea annularis. Mar Ecol Prog Ser 367:143-152

> González-Rivero M, Ferrari R, Schönberg CHL, Mumby PJ (2012) Impacts of macroalgal competition and parrotfish predation on the growth of a common bioeroding sponge. Mar Ecol Prog Ser 444:133-142

> Greenberg DF (2004) Applied longitudinal data analysis: modeling change and event occurrences. Sociol Methods Res 33:305-308

Haas A, el-Zibdah M, Wild C (2010) Seasonal monitoring of coral-algae interactions in fringing reefs of the Gulf of Aqaba, Northern Red Sea. Coral Reefs 29:93-103

Hay ME (1981) Herbivory, algal distribution, and the maintenance of between-habitat diversity on a tropical fringing reef. Am Nat 118:520-540

Hay ME (2009) Marine chemical ecology: chemical signals and cues structure marine populations, communities, and ecosystems. Annu Rev Mar Sci 1:193-212

Hedley J (2006) VidAna. Marine Spatial Ecology Lab, University of Exeter. Www.marinespatialecologylab.org/ resources/vidana/

Hughes TP (1989) Community structure and diversity of coral reefs - the role of history. Ecology 70:275-279

Hughes TP (1994) Catastrophes, phase shifts, and largescale degradation of a Caribbean coral reef. Science 265: 1547-1551

Hughes TP, Tanner JE (2000) Recruitment failure, life histories, and long-term decline of Caribbean corals. Ecology 81:2250-2263

> Hughes TP, Rodrigues MJ, Bellwood DR, Ceccarelli D and others (2007) Phase shifts, herbivory, and the resilience of coral reefs to climate change. Curr Biol 17:360-365

Jompa J, McCook LJ (2002a) Effects of competition and herbivory on interactions between a hard coral and a brown alga. J Exp Mar Biol Ecol 271:25-39

> Jompa J, McCook LJ (2002b) The effects of nutrients and 
herbivory on competition between a hard coral (Porites cylindrica) and a brown alga (Lobophora variegata). Limnol Oceanogr 47:527-534

Kramer PA, Kramer PR, Ginsburg RN (2003) Assessment of the Andros island reef system, Bahamas (Part 1: Stony corals and algae). Atoll Res Bull 496:76-99

Kuffner IB, Walters LJ, Becerro MA, Paul VJ, RitsonWilliams R, Beach KS (2006) Inhibition of coral recruitment by macroalgae and cyanobacteria. Mar Ecol Prog Ser 323:107-117

Lang JC, Chornesky EA (1990) Competition between scleractinian reef corals - a review of mechanisms and effects. In: Dubinsky Z (ed) Ecosystems of the world 25: Coral reefs. Elsevier, Amsterdam, p 209-252

Lirman D (2001) Competition between macroalgae and corals: effects of herbivore exclusion and increased algal biomass on coral survivorship and growth. Coral Reefs 19:392-399

McClanahan TR, Muthiga NA (1998) An ecological shift in a remote coral atoll of Belize over 25 years. Environ Conserv 25:122-130

McClanahan TR, Aronson RB, Precht WF, Muthiga NA (1999) Fleshy algae dominate remote coral reefs of Belize. Coral Reefs 18:61-62

> McCook L, Jompa J, Diaz-Pulido G (2001) Competition between corals and algae on coral reefs: a review of evidence and mechanisms. Coral Reefs 19:400-417

McGuire MP (1998) Timing of larval release by Porites astreoides in the northern Florida keys. Coral Reefs 17:369-375

Meesters EH, Wesseling I, Bak RPM (1996) Partial mortality in three species of reef-building corals and the relation with colony morphology. Bull Mar Sci 58:838-852

> Meesters EH, Wesseling I, Bak RPM (1997) Coral colony tissue damage in six species of reef-building corals: partial mortality in relation with depth and surface area. J Sea Res 37:131-144

Mumby PJ (1999) Bleaching and hurricane disturbances to populations of coral recruits in Belize. Mar Ecol Prog Ser 190:27-35

Mumby PJ (2006) The impact of exploiting grazers (Scaridae) on the dynamics of Caribbean coral reefs. Ecol Appl 16:747-769

> Mumby PJ, Harborne AR (2010) Marine reserves enhance the recovery of corals on caribbean reefs. PLoS ONE 5:e8657

Mumby PJ, Steneck RS (2008) Coral reef management and conservation in light of rapidly evolving ecological paradigms. Trends Ecol Evol 23:555-563

Mumby PJ, Foster NL, Fahy EAG (2005) Patch dynamics of coral reef macroalgae under chronic and acute disturbance. Coral Reefs 24:681-692

Mumby PJ, Dahlgren CP, Harborne AR, Kappel CV and others (2006a) Fishing, trophic cascades, and the process of grazing on coral reefs. Science 311:98-101

> Mumby PJ, Hedley JD, Zychaluk K, Harborne AR, Blackwell PG (2006b) Revisiting the catastrophic die-off of the urchin Diadema antillarum on Caribbean coral reefs: fresh insights on resilience from a simulation model. Ecol Modell 196:131-148

> Mumby PJ, Hastings A, Edwards HJ (2007) Thresholds and the resilience of Caribbean coral reefs. Nature 450:98-101

> Nugues MM, Bak RPM (2006) Differential competitive abilities between Caribbean coral species and a brown alga: a year of experiments and a long-term perspective. Mar Ecol Prog Ser 315:75-86

Nugues MM, Delvoye L, Bak RPM (2004) Coral defense against macroalgae: differential effects of mesenterial filaments on the green alga Halimeda opuntia. Mar Ecol
Prog Ser 278:103-114

Paul VJ, Kuffner IB, Walters LJ, Ritson-Williams R, Beach KS, Becerro MA (2011) Chemically mediated interactions between macroalgae Dictyota spp. and multiple life-history stages of the coral Porites astreoides. Mar Ecol Prog Ser 426:161-170

Rasher DB, Hay ME (2010) Chemically rich seaweeds poison corals when not controlled by herbivores. Proc Natl Acad Sci USA 107:9683-9688

Rasher DB, Stout EP, Engel S, Kubanek J, Hay ME (2011) Macroalgal terpenes function as allelopathic agents against reef corals. Proc Natl Acad Sci USA 108: 17726-17731

- Renken H, Mumby PJ (2009) Modelling the dynamics of coral reef macroalgae using a Bayesian belief network approach. Ecol Modell 220:1305-1314

Renken H, Mumby PJ, Matsikis I, Edwards HJ (2010) Effects of physical environmental conditions on the patch dynamics of Dictyota pulchella and Lobophora variegata on caribbean coral reefs. Mar Ecol Prog Ser 403:63-74

River GF, Edmunds PJ (2001) Mechanisms of interaction between macroalgae and scleractinians on a coral reef in Jamaica. J Exp Mar Biol Ecol 261:159-172

> Rogers CS, Fitz HC, Gilnack M, Beets J, Hardin J (1984) Scleractinian coral recruitment patterns at Salt River submarine canyon, St. Croix, U.S. Virgin islands. Coral Reefs 3:69-76

Sammarco PW (1980) Diadema and its relationship to coral spat mortality: grazing, competition, and biological disturbance. J Exp Mar Biol Ecol 45:245-272

Sammarco PW (1982) Effects of grazing by Diadema antillarum Philippi (Echinodermata, Echinoidea) on algal diversity and community structure. J Exp Mar Biol Ecol 65:83-105

Sebens KP (1982) The limits to indeterminate growth: an optimal size model applied to passive suspension feeders. Ecology 63:209-222

Smith RB, Jiang QF, Doyle JD (2006) A theory of gravity wave absorption by a boundary layer. J Atmos Sci 63: $774-781$

> Soong K (1993) Colony size as a species character in massive reef corals. Coral Reefs 12:77-83

Tanner JE (1995) Competition between scleractinian corals and macroalgae: an experimental investigation of coral growth, survival and reproduction. J Exp Mar Biol Ecol 190:151-168

> Titlyanov EA, Yakovleva IM, Titlyanova TV (2007) Interaction between benthic algae (Lyngbya bouillonii, Dictyota dichotoma) and scleractinian coral Porites lutea in direct contact. J Exp Mar Biol Ecol 342:282-291

Turon X, Becerro MA (1992) Growth and survival of several ascidian species from the northwestern Mediterranean. Mar Ecol Prog Ser 82:235-247

> Vermeij MJA, Sandin SA (2008) Density-dependent settlement and mortality structure the earliest life phases of a coral population. Ecology 89:1994-2004

Whelan K, Miller J, Sanchez O, Patterson M (2007) Impact of the 2005 coral bleaching event on Porites porites and Colpophyllia natans at Tektite reef, US Virgin Islands. Coral Reefs 26:689-693

> Zilberberg C, Edmunds PJ (2001) Competition among small colonies of Agaricia: the importance of size asymmetry in determining competitive outcome. Mar Ecol Prog Ser 221:125-133

Zuur AF, Ieno EN, Elphick CS (2010) A protocol for data exploration to avoid common statistical problems. Methods Ecol Evol 1:3-14 